\title{
Prosecution of Rhino Poachers: The Need to Focus on Prosecution of the Higher Echelons of Organised Crime Networks
}

\author{
Robert Doya Nanima \\ LLD Candidate and Graduate Lecturing Assistant, Faculty of Law, University of \\ the Western Cape, Cape Town, South Africa \\ rnanima@gmail.com
}

\begin{abstract}
There has been a focus on the prosecution of persons who are arrested in the course of poaching rhinos in national parks, other than the members who form the higher echelons of the networks. This contribution advances the argument that there is need to create a framework that leads to the prosecution of the higher echelons of the organised crime groups, who are usually beyond South Africa's borders. To advance this argument, the author evaluates the classification system of networks, the legal regime and the prosecutorial gaps and the evaluation system of progress employed by the National Prosecuting Authority and the Department of Environmental Affairs. Recommendations for reform follow.
\end{abstract}

\section{Keywords}

Conviction rates - classification - higher echelons - networks - prosecution - rhino poachers

\section{Introduction}

From 2008, there has been a significant increase in rhino horn poaching in South Africa to meet the demand in the Asian markets of China ${ }^{1}$ and

1 Ellis Katherine, 'Tackling the demand for the rhino horn' (Save the rhino) $<$ https://www.sa vetherhino.org/rhino_info/thorny_issues/tackling_the_demand_for_rhino_horn > accessed 27 December 2016. 
Vietnam. ${ }^{2}$ This poaching is attributed to Organised Crime Groups (networks) operating within South Africa, Mozambique, and East Asia. ${ }^{3}$ This article seeks to state that there is need to refocus on the prosecution of the higher echelons of the organised crime groups who are usually beyond South Africa's borders. This contribution is divided into four sections, which evaluates the classification system of networks, and the conviction rate system as the yardstick for progress which points to arrests in the parks. The third section evaluates the legal regime and the prosecutorial gaps, to show that the laws focus on crimes committed within South Africa. The conclusion offers a framework on areas for reform. The author employs an analysis of primary sources, legal literature, and legislation among other sources to guide the study.

There are various definitions of networks, which are instructive in tailouring a definition for this article. An organised crime group or network involves coordination and commission of a serious crime, by people working together on a continuing basis motivated by many factors including financial gain. ${ }^{4}$ This definition does not place a geographical jurisdiction to the activities of the networks. A network may also refer to transnational, national, or local groupings of highly centralised enterprises run by criminals engaging in illegal activity, for various reasons, like money, and political motivation. ${ }^{5}$ This definition fails to address the issue of continuity in networks. ${ }^{6}$ McCarry's definition ${ }^{7}$ indicates the same shortfall by referring to a network as a group with a formalised structure, and a primary objective of obtaining money through illegal activities. The United Kingdom's National Criminal Intelligence Service (NCIS) attaches four attributes to the networks. ${ }^{8}$ First, it contains at least three people; ${ }^{9}$ secondly, it engages in criminal activity for an indefinite period. ${ }^{10}$ Thirdly, the network

2 JW Herbig \& ML Griffiths 'Conservation crime and rhinoceros poaching: from ancient custom to modern dilemma' (2016) 29(1) Acta Criminologica: South African Journal of Criminology 129, 132, 142.

3 Herbig and Griffths (2016) 130-134.

4 Organised Crime Groups, 'National Crime Agency', <http://www.nationalcrimeagency .gov.uk/crime-threats/organised-crime-groups> accessed 23 December 2016.

5 JJ Macionis and LM Gerber, Sociology (Canadian edn, Pearson Canada 2010) 206.

$6 \quad$ MD Lyman and GW Potter Organized Crime (4edn, Pearson Education 2007) 7.

7 McCarry Mike, 'Organized Crime: The role of the Federal Government' <http://www .slideshare.net/guest278081/organized-crime> accessed 25 December 2016.

8 Lyman and Potter (2007) 5.

$9 \quad$ Lyman and Potter (2007) 5 .

$10 \quad$ Lyman and Potter (2007) 5. 
is motivated by profit or power, ${ }^{11}$ and fourthly it commits serious criminal offences. ${ }^{12}$

The first three preceding definitions complement each other with regard to illegal activities, which are coordinated for various goals. The fourth definition from the United Kingdom places these activities at a local, national, and transnational setting. ${ }^{13}$ With regard to a definition from South Africa, the South Africa Police Service Act (sAPs Act) provides a list of circumstances, which present organised crime. It provides that activities:

(a) by a person, group of persons or syndicate acting in -

(i) an organised fashion; or

(ii) a manner which could result in substantial financial gain for the person, group of persons or syndicate involved.

(e) in respect of the hunting, importation, exportation, possession, buying and selling of endangered species or any products thereof as may be prescribed;

(f) in more than one province or outside the borders of the Republic by the same perpetrator or perpetrators, and in respect of which the prevention or investigation at national level would be in the national interest. ${ }^{14}$

This list of circumstances creates distinct features of these networks. First, the existence of an organised structure, and secondly, for the prospect of financial gain. Thirdly, with regard to poaching of endangered species, and fourthly the crimes may require a concerted transnational effort in conducting investigations. The concept of 'organised fashion' in section 16(1) (a) is qualified to ongoing, continuous or repeated participation of at least two incidents of criminal activities. It would appear that this qualification is for the purpose of qualifying a crime as organised crime, other than a basis for the prosecution of the culprits. This definition is in consonance with the fourth definition as far as it refers to a network as a group of more than three persons, engaging in illegal activities of a serious nature, across national borders for an indefinite period, through centralised enterprises and structures, with goals, which are not limited to making profits. ${ }^{15}$ This article adopts the definition by the SAPs Act.

\footnotetext{
11 Lyman and Potter (2007) 5.

12 Lyman and Potter (2007) 5 .

13 Macionis, and Gerber (2010) 206.

14 The South African Police Service Act 68 of 1995, s 16 (1) (a), (e), (f).

15 The South African Police Service Act 68 of 1995, s 16 generally.
} 
Networks may be classified by, their structures and operation, activities, and their social, cultural and historical conditions of operation. ${ }^{16}$ This section places emphasis on their hierarchy and activities. A standard hierarchical structure presents three levels, with a leader, who oversees the activities other leaders below him. ${ }^{17}$ These leaders, in turn, foresee the activities of the groups of individuals who are directly answerable to them..$^{18}$

This hierarchical structure's basis on social relations instead of market dynamics affects the networks' successful participation in modern global markets. It may present fundamental flaws as far as it fails to capture the changing trends in the global economy. ${ }^{19}$ Standing ${ }^{20}$ agrees with Lyman \& Potter that most networks often involve the use of a loose and highly changeable association of people who relate to networks, instead of unique career criminals. ${ }^{21} \mathrm{His}$ point of departure is in the recognition that the study of networks in South Africa in based on the internal characteristics of networks, which present a hierarchical structure. ${ }^{22}$ Standing's study is focused on networks in South Africa, while Lyman \& Potter focus on the European economies. It is, therefore, prudent to establish practical applications of the hierarchical system in a geographical setting before one rules out its operation. ${ }^{23}$

16 V Le 'Organised Crime Typologies: Structure, Activities and Conditions' (2012) 1 International Journal of Criminology and Sociology 121, 121-131;

17 Global programme against transnational organized. Crime Results of a pilot survey of forty selected organized criminal groups in sixteen countries, September 2002.

18 Global programme against transnational organized. Crime Results of a pilot survey of forty selected organized criminal groups in sixteen countries, September 2002. networks embrace six hierarchical models, which include the standard hierarchy, regional hierarchy, clustered hierarchy, core group, and the criminal network. An evaluation of the six models is beyond the scope of this paper, and emphasis rests on the standard hierarchy.

19 Lyman and Potter (2007) 7.

20 S Andre 'Re-conceptualising organised crime' (2003)12(2) African Security Review 103, 103.

21 Standing (2013) 103.

22 Standing (2013) 103.

23 Carinsky, 'Organised Crime Investigation Course to SAPS' < http://web.vdw.co.za/Portals/ 25/Documents/Conventions/2014/What\%2ocan\%2obe\%2odone\%2oto\%2oeffectively\% 2ocombat\%2oorganized\%20crime_Col\%2oCarlinsky.pdf> accessed 27 December 2016. 
Secondly, the classification of the networks with regard to their activities ${ }^{24}$ relates to their business and economic considerations, and market dynamics. ${ }^{25}$ This presents an enterprise or a corporate identity, whereby activities are rationalised from a business sense in terms of consideration of new business opportunities, market changes, and profits. ${ }^{26}$ The subsequent transnational operations of the networks ${ }^{27}$ make it difficult for a government to monitor its activities. ${ }^{28}$ This makes networks synonymous with multinational corporations if the later are carrying out criminal activities under the guise of a corporate entity. In Colombia, for instance, MNCs have been often accused of trafficking narcotics and arms. ${ }^{29}$ This is evident in setting up private zoos in South East Asia for the purposes of exporting rhinos from South Africa, ${ }^{30}$ and the use of legally established businesses as conduits for illegal dealing in rhino horns. ${ }^{31}$

Hendrik and Daffue ${ }^{32}$ harmonise the hierarchy and activities of networks by illustrating their operations in three stages of, collection, transportation, and distribution. ${ }^{33}$ The collection stage has a leader at the local or inter-provincial stage who coordinates the activities of a poaching gang, which involves scouts, drivers, shooters, and cutters. ${ }^{34}$ The leader delivers the rhino horn to the

24 Vy Lee (2013) generally.

25 Williams Phil and Godson Roy 'Anticipating organized and transnational crime' [2002] 37

(4) Crime, Law and Social Change 311.

26 Williams, and Godson (2002) 311-355.

27 Tlou and Others $v S[2015]$ ZAGPPHC 86.

28 D Barbara, 'Differences and Similarities between Corporate and Organized Crime' (Barbara's Dozier Blog, 13 January 2013) <https://barbradozier.wordpress.com/2012/ o1/13/differences-and-similarities-between-corporate-and-organized-crime/> accessed 26 December 2016.

29 L Dowell, (2008) 'Transnational corporations found guilty of serious crimes' '(Workers. org 31 July 2008) <http://www.workers.org/2008/world/colombia_0807/> accessed 15 February 2016.

$30 \quad$ J Radmeyer (2016) 'Global Initiative Against Transnational Crime’ (Global Initiative, (2016) at http://globalinitiative.net/rhino-tipping-point/ (accessed 27 December 2016).

31 L Neme, 'U.S. Indictment Accuses South African Brothers of Trafficking Rhino Horns' $<$ http://news.nationalgeographic.com/news/2014/10/141023-rhino-wildlife-trafficking -south-africa-safari-club-nra-lacey-act-hawks-operation-crash-groenewalds/> accessed 27 December 2016.

32 Daffue, Hendrik \& Elise Daffue (2013): Rhino horn conduits-organized crime stages. Pretoria: Stop Rhino Poaching, in Hübschle AM 'A game of thorns Transnational Flows of Rhino Horn' (2016) International Max Planck Research School 37.

33 Hendrik and Daffue (2013).

34 Hendrik and Daffue (2013). 
local receivers who procure the same to national exporters or international receivers. The members of the poaching gang perform the actual rhino poaching. Their direct involvement makes them susceptible to arrest and prosecution ${ }^{35}$ because they usually operate within South Africa's borders.

The second stage is the transporting stage, with a triangular structural activity braced by receivers, national exporters, the international receivers of the rhino horn and the Kingpins. ${ }^{36}$ The national exporters form the basis of this structure, and they procure the horns to the international receivers, who in turn procure the horns to the kingpins. ${ }^{37}$ The national exporters link the transportation with the distribution (third) stage, through the distribution of the horns to the East Asia Markets. ${ }^{38}$ They supply the first distributor, who supplies the second distributor, who in turn offers the final product to the consumer. ${ }^{39}$ The National Exporters and Receivers who procure the horn to the international exporters are prosecuted if arrested within South Africa. ${ }^{40}$

On the international plane, South Africa, Mozambique and Vietnam are parties to the Convention on International Trade in Endangered Species of Wild Fauna and Flora (CITES), ${ }^{41}$ which regulates international trade in endangered species. However, South Africa has signed a number of agreements with Vietnam, the most recent being a memorandum of understanding (MoU) ${ }^{42}$ The MoU neither provides nor envisages a framework to enforce the protection of rhinos from poachers. The poachers form the collection groups illustrated in Hendricks and Daffue's model. It provides for different forms of cooperation, other than cooperation in the prosecution of the high enclaves of the

35 Senior Prosecutor of environmental crime, Ansie Venter refers to many arrests of poachers in the National Parks <http://showcase.news24.com/prosecutor-proud-of-her -success-rate/> accessed 3 January 2017.

$36 \quad$ Hendrik and Daffue (2013).

37 Hendrik and Daffue (2013).

38 Hendrik and Daffue (2013).

39 Hendrik and Daffue (2013).

$40 \quad$ Lemthongthaiv S (849/2013) [2014] ZASCA 131.

41 South Africa ratified the Cites on 15 July 1975, entered into force 13 October 1975. Mozambique acceded to it on 25 March 1981, entered into force on 23 June 1981, while Vietnam acceded to the same on 20 January 1994, entered into force 20 April 1994, $<$ https://cites.org/eng/disc/parties/chronolo.php> accessed 5 January 2017).

42 Memorandum of Understanding $(\mathrm{MoU})$ between the Government of the Socialist Republic of Viet Nam and the Government of the Republic of South Africa on cooperation on biodiversity conservation and protection, dated 12 December $2012<\mathrm{https} / / \mathrm{www}$ .environment.gov.za/sites/default/files/legislations/mou_vietnam_sa2012.pdf> accessed 5 January 2017. 


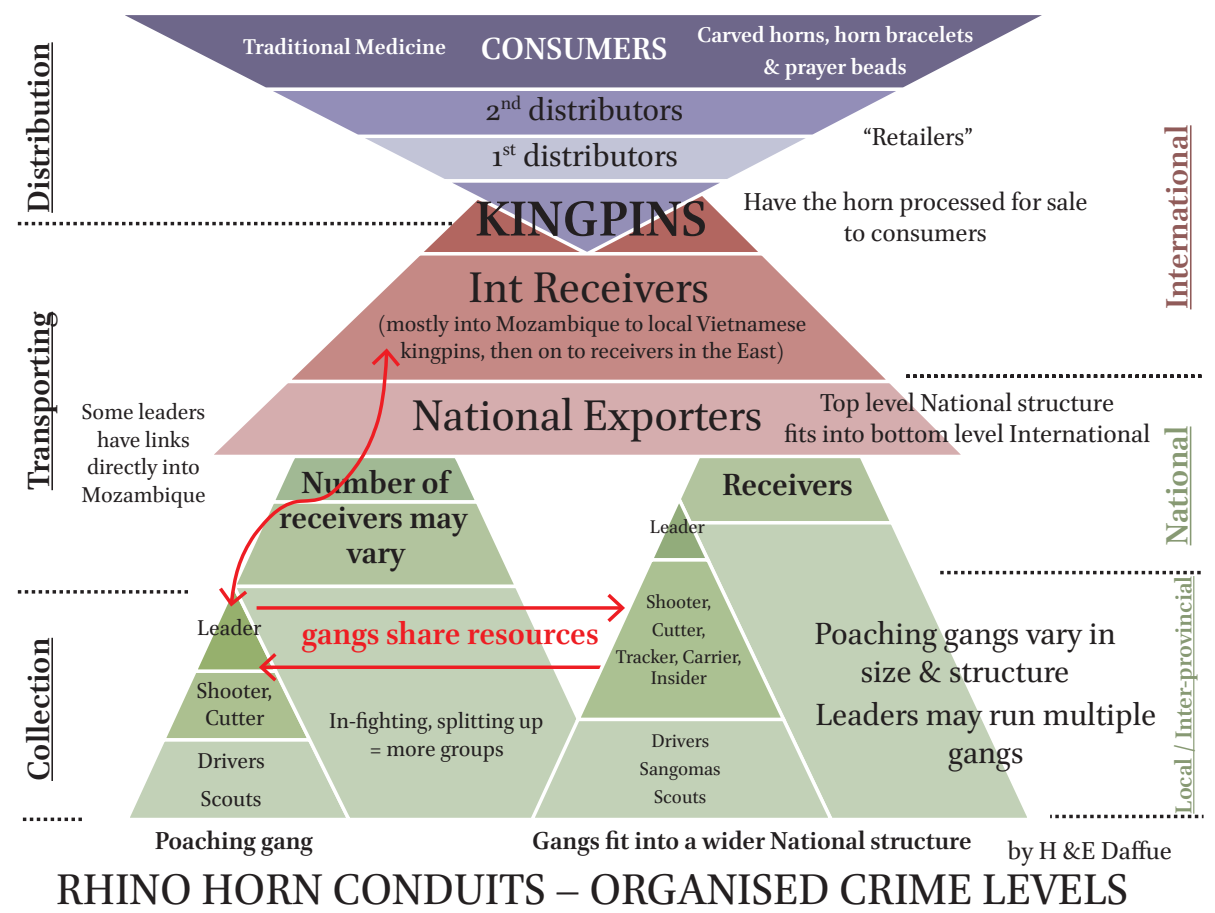

SOURCE: HENDRICKE AND DIFFUE (2013), IN HÜBSCHLE (2016) 37.

networks. ${ }^{43}$ Vietnam continues to deny any role of its nationals in the illegal rhino horn trade in South Africa, ${ }^{44}$ despite the arrest of 24 of its nationals as part of the 43 suspects of rhino-related crimes. ${ }^{45}$ This shows that prosecution of higher echelons of networks depends on their arrest within South Africa. ${ }^{46}$ It follows that the higher echelons do not form the poaching gangs who perform the actual tasks of poaching in the parks. It is significant to establish the mode of evaluation of progress in the fight against rhino poaching.

\footnotetext{
$43 \mathrm{MoU}(2012)$, art. 3 .

44 Vietnam Environment Administration, Rhino Horn Claim Unfounded, 4 September 2012, $<$ http://vea.gov.vn/en/news/news/Pages/Rhino-horn-claim-unfounded.aspx > accessed 27 December 2016.

45 Vietnam Environment Administration, Rhino Horn Claim Unfounded, 4 September 2012, <http://vea.gov.vn/en/news/news/Pages/Rhino-horn-claim-unfounded.aspx> accessed 27 December 2016).

46 Sheriden Kerry, U.S. Rhino Horn Trafficking Draws Motley Profiteers, AFP, 10 May, 2012 $<$ http://www.allvoices.com/news/12126350-us-rhino-horn-trafficking-draws-motley -profiteers> 30 December 2016).
} 
The Department of Environmental Affairs announced that as at 31 August 2016, 414 alleged poachers have been arrested across South Africa. ${ }^{47}$ Between January and the end of August 2016, a total number of 796 rhinos were poached nationally, and Kruger national park reported that 458 poached rhino carcasses were found therein, compared to 557 in $2015 .{ }^{48}$ This represents a $17.8 \%$ decline in the number of rhino carcasses. This calculation is based on the percentage of the number of carcasses against the number of live rhinos reduced. While this shows a decline in the poaching, there were 2115 illegal incursions into Kruger national park, which represented an increase of $27.87 \%{ }^{49}$ This reflects 414 arrests in the same period, whereby 177 are from Kruger national park. ${ }^{50}$ This accounts for arrests of $52 \%$ of the alleged poachers with $38 \%$ from Kruger national park. Although these arrests show that $73 \%$ of the poachers in the country are from Kruger national park, the number of rhino carcasses is still high compared to the arrests. To get a better depiction, one has to establish the conviction rate of the rhino poachers.

The National Prosecuting Authority (NPA) states that it achieved a high conviction rate of $95.2 \%$, with 357 convictions out of 375 cases with a verdict. ${ }^{51}$ While it is desirable to think that out of 414 poachers arrested in 2016, 375 were prosecuted and 357 were convicted, it is not the case. According to the South African Law Commission, conviction rates can be expressed in terms of the numbers of cases that go to trial or in terms of the numbers of cases reported to the police. ${ }^{52}$ With regard to trial-based perspective, the statistics from pros-

47 Statistics as at August 2016, on rhino poaching, by the Department of Environmental Affairs, <https://www.environment.gov.za/mediarelease/molewa_highlightsprogress_ onrhinopoaching2016 > accessed 15 February 2017.

48 Statistics as at August 2016, on rhino poaching, by the Department of Environmental Affairs, <https://www.environment.gov.za/mediarelease/molewa_highlightsprogress_ onrhinopoaching2016> accessed 15 February 2017.

49 Statistics as at August 2016, on rhino poaching, by the Department of Environmental Affairs, <https://www.environment.gov.za/mediarelease/molewa_highlightsprogress_ onrhinopoaching2016> accessed 15 February 2017.

50 Statistics as at August 2016, on rhino poaching, by the Department of Environmental Affairs, <https://www.environment.gov.za/mediarelease/molewa_highlightsprogress_ onrhinopoaching2016 $>$ accessed 15 February 2017.

51 The NPA Annual Report 2015/2016, 38 <https:/www.npa.gov.za/sites/default/files/ annual-reports/NPA\%20Annual\%2oReport\%201516.pdf> accessed 15 February 2017.

52 Research Paper 18, Project 82, Conviction rates and other outcomes of crimes reported in eight South African police areas, <http://www.justice.gov.za/salrc/rpapers/rp18.pdf> accessed 15 February 2017. 
ecution or courts focus on the cases that go to trial..$^{53}$ The cases that are not detected by police or are withdrawn tend to inflate the conviction rate, which is deceptive as far as it does not depict an offender's accountability for a crime. ${ }^{54}$ Conversely, the report-based perspective calculates the conviction rate with regard to the numbers of crimes reported to the police. ${ }^{55}$ This approach offers a clear and realistic position of cases that are successfully investigated and followed. The NPA uses the trial-based perspective and defines a conviction rate to mean

the percentage of cases finalised with a verdict in which a guilty verdict is obtained. ${ }^{56}$

This is calculated by obtaining the percentage of the convictions including guilty verdicts under section $57 \mathrm{~A}$ of the Criminal Procedure Act divided by the number of cases a verdict. ${ }^{57}$ Therefore, the computation of the conviction rate of $95.2 \%$ does not include the number of arrests, or the number of carcasses of the rhino against the reducing live rhinos. In addition, the conviction rate is measured at the date of sentencing or returning a verdict of not guilty without regard to the date the plea was entered..$^{58}$ It follows, therefore, that the conviction for a given year includes cases, where the plea was not taken in the year under review. While the DEA reports arrests within a given period, the conviction rate reports are based on the date of sentencing, entry of a plea of guilt or passing of a verdict. In addition, this rate includes other environmental crimes, such as illegal hunting, dealing, and possession of ivory, abalone, cycads, waste and pollution cases among others. ${ }^{59}$ It is the author's view that conviction rates, based on finalised cases in a year are an unreliable measure of success in rhino poaching as an environmental crime. This means that if a court convicts the accused in 8 out of 10 cases, then its conviction rate is $80 \%$.

If the conviction rate was to be determined by the summation of the number of rhinos killed or poached, a number of suspects arrested, prosecuted, and against who charges that were dropped, would be far less that the $95.2 \%$. The NPA's policy of prosecution of cases with a realistic prospect of a conviction is not enough to justify the conviction rates because they present a poor

\footnotetext{
53 Research Paper 18, 9.

54 Research Paper 18, 9 .

55 Research Paper 18, 9.

56 The NPA Annual Report 2015/2016, 77.

57 The NPA Annual Report 2015/2016, 77.

58 The NPA Annual Report 2015/2016, 77.

59 The NPA Annual Report 2015/2016, 77.
} 
comparison to the number of rhinos killed and cases reported to police on an annual basis. ${ }^{60}$ It is, however important to scrutinise the source of this realistic prospect of a conviction. Most crimes, generally, which are reported to the police, are not forwarded to court. ${ }^{61}$ Some may be referred to as undetected because of failure by the police to identify a suspect. ${ }^{62}$ It may also be to lack of leads, poor police investigations or lack of community cooperation. ${ }^{63}$ At times, the cases may be withdrawn by the police, upon request by the complainant, and or with the consent of the prosecution. ${ }^{64}$ It is, however, inconceivable that facts, which present a suspect arrested in the act of poaching, or whether the complainant is a game ranger would go undetected or be withdrawn. In addition, this section shows that it the poachers in the first level of activity, who are usually arrested and prosecuted. The second and third levels minimally reflect in the reports of the NPA and the DEA. A review of the legal regime is instructive to achieving a nuanced approach to the core of the problem.

The National Environmental Management Act (NEMA) ${ }^{65}$ lays down the national environmental principles, ${ }^{66}$ which are instructive in informing the procedures for cooperative governance, ${ }^{67}$ fair decision-making, and conflict management, ${ }^{68}$ integrated environmental management, ${ }^{69}$ issues of international obligations and duties. ${ }^{70}$ The NEMA also deals with compliance and enforcement of environmental laws ${ }^{71}$ and administrative matters that deal with the environmental management acts. ${ }^{72}$ While section $2(4)(b)$ (viii) of NEMA, may be used to anticipate and prevent negative impacts on the environment and environmental rights, or minimise the effects, it does little in offering

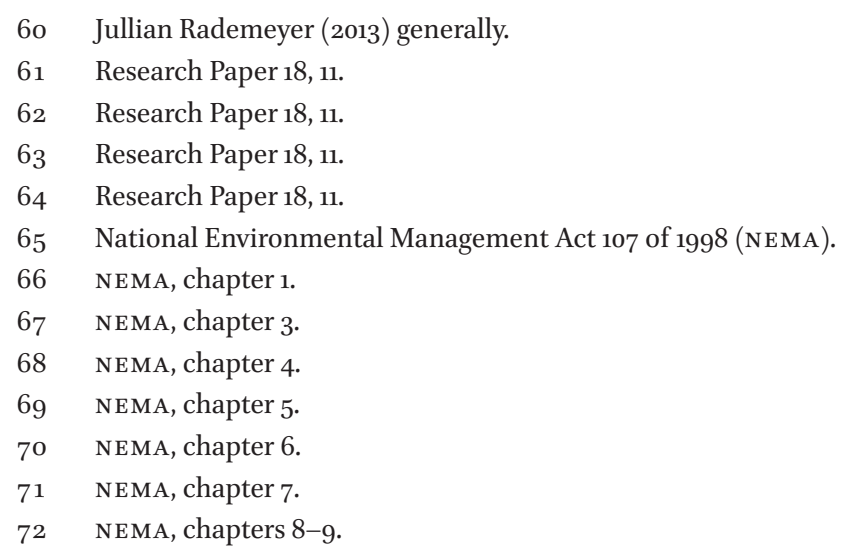


a working framework that prevents the dealing in endangered species such as rhinos or the prosecution of crime syndicates. The National Environmental and Biodiversity Act ${ }^{73}$ defines endangered species and restricts any activities that involve endangered species. ${ }^{74}$ The NEMBA deals with potential offenders, with regard to being arrested in the course of dealing in endangered species. It does no elucidate on the mode of operation in the event that law enforcement establishes the identity of the members of the networks.

South Africa enacted the Prevention of organised crime (POOCA), ${ }^{75}$ against the backdrop that common law and statutory law is ineffective in dealing with organised crime. ${ }^{76}$ Usually, a suspect is charged with conspiracy to commit a statutory offence by performing a restricted activity of hunting and killing of rhinos in a national park, possession of a hunting rifle without a licence; the possession of ammunition without a licence or a permit to possess such ammunition. ${ }^{77}$ Despite the existence of the two Acts, there remains a difficulty in the identification and prosecution of persons who use the poachers to get involved in rhino poaching. However, it recognises the structure of the networks and the direct involvement of its leaders. ${ }^{78}$ Thirdly, that in a bid to prevent persons from benefiting from organised crime, the POOCA uses preservation and forfeiture of the property concerned in the commission of the offence. ${ }^{79}$ The success of the war against organised crime is evident in the successful prosecution of the leaders of the networks, within and outside South Africa. The key question at this point is whether the third basis, offers the POocA with the ability to prosecute, before forfeiture of the property, and whether the emphasis is on the key leaders of the networks or the poachers.

\section{$5 \quad$ Prosecutorial Gaps}

There are several gaps in the prosecution, which are instructive in presenting dilemmas in prosecution. The suspects who are arrested, are dispensable who do the actual poaching at lower fees, while the individuals who orchestrate

\footnotetext{
73 National Environmental and Biodiversity Act Act 10 of 2004 (NEMBA).

74 NEMBA Section 56.

75 Prevention of organised crime Act 121 of 1998 (POOCA).

76 PoocA, preamble, para 7 .

77 Sehlabela and Others $v S\left(\mathrm{~A}_{723} / 2014\right)$ [2014] ZAGPPHC 847 (13 October 2014) para 4. See also Mkhabela and Others $v S$ (A334/15) [2016] ZAG P PHC 936 (8 November 2016).

78 POOCA, preamble, para 8.

79 POOCA, preamble, para 9.
} 
the crimes are rarely arrested.$^{80}$ Usually, the suspects who need to make a living, are always dispensed with upon arrest, and others are conscripted into the vice. This leads to the prosecution of the suspects at the low end of the criminal chain, leaving the higher enclaves of organised crime intact and flourishing. ${ }^{81}$ The consistent arrest and prosecution of the lower members of the group is not a viable alternative in the long run because the higher echelons will always get other poachers to continue with the vice.

As noted in the preceding paragraph, the limitation of the system in prosecuting the leaders of the networks as the key contractors in the commission of the offence presents a prosecutorial gap. The poachers, who are usually arrested are seldom aware of the final consumer, as far as they are contracted to procure the rhino horns and deliver them to a particular individual or group of individuals who are shrouded in mystery. These transactions by their nature, present a hierarchical system in the rhino horn poaching. The absence of a tailoured legal regime, which reflects the nature of rhino poaching, the existence of crime organisations that supercede criminal gangs within South Africa or money laundering schemes is a dilemma. This prosecutorial dilemma fails to deals with the persons who orchestrate the poaching of the rhino horns from the National Parks to the final consumers who are beyond the bounds of South Africa.

South Africa is a party to the CITES agreement. South Africa signed a memorandum of understanding (MOU) with Vietnam as a way of curbing rhino poaching, aimed at curbing rhino poaching, promoting cooperation in law enforcement, and compliance with the Convention on International Trade in Endangered Species of Wild Fauna and Flora (CITES). ${ }^{82}$ Unfortunately, South Africa does not have any extradition agreement with Vietnam..$^{83}$ As a result, individuals who belong to the networks enclaves cannot be prosecuted due to lack of a law that allows extraterritorial jurisdiction and the use of an extradition treaty to enable South Africa to prosecute leaders of networks in Vietnam.

8o Tlou and Others $v S$ [2015] zAG PPHC 86 (13 February 2015).

81 Kimiko; South Africa's ongoing problem with Rhino Poaching only gets worse $<\mathrm{http} / / /$ www.wildlifeplanet.net/south-africarsquos-ongoing-problem-with-rhino-poaching -only-gets-worse.html> accessed 24 December 2016.

82 Cota-Larson, Rhishja South Africa and Vietnam Sign Agreement to Curb Rhino Horn Trafficking 10 December 2012 <http://annamiticus.com/2012/12/10/south-africa-and -vietnam-sign-agreement-to-curb-rhino-horn-trafficking/> accessed 30 December 2016).

83 Extradition and Mutual Legal Assistance in criminal matters treaties $<\mathrm{http} / / \mathrm{www}$.justice .gov.za/ilr/mla.html> (accessed 3o December 2016). 
The current legal regime is sufficient in part, in prosecuting rhino poaching within South Africa. ${ }^{84}$ Extraterritorial jurisdiction should be introduced in the laws, by inculcating the various stages that networks present, other than the collection stage. ${ }^{85}$ Extraterritorial jurisdiction will offer a more nuanced approach in prosecution across the stages of transportation and distribution, which takes place beyond the borders of South Africa. This will offer a more nuanced approach in prosecution across the stages of transportation and distribution, which takes place beyond the borders of South Africa.

South Africa should conclude Extradition Agreements ${ }^{86}$ with countries that are used as conduits for the rhino horn transportation and distribution, such as Mozambique and Vietnam. She can use the diplomatic means to have the agreement, through the use of the SADC protocol on extradition. ${ }^{87}$ These agreements will ensure the prosecution of international receivers, kingpins, and distributors. A revision of the MoU between South Africa and Vietnam is instructive in ensuring cooperation. This includes extraditing individuals and enterprises that benefit from the continued poaching of rhino horns.

\section{Conclusion}

South Africa has to rejuvenate her diplomatic relations with Vietnam and engage in the conclusion of extradition agreements. This is because Vietnam has a role in the increased poaching of rhinos in South Africa due to the former's demand for rhino horn for recreational consumption and as medicine. ${ }^{88}$ Secondly, Vietnam has failed to embrace strategies to reduce the demand and

84 The Prevention of Organised Crime Act 121 of 1998, National Environmental Management: Protection Act 57 of 2003, National Environmental and Biodiversity Act 10 of 2004, among other laws.

85 South Africa has some laws that deal with extraterritorial jurisdiction such as the Prevention and Combating and Torture of Persons Act 13 of 2013, sec. 6(1), and Implementation of the Rome Statute of the International Criminal Court Act 27 of 2002, sec. 4.

86 In accordance with the Extradition Act 67 of 1962.

87 SADC Protocol on extradition, art $2<$ http://www.sadc.int/files/3513/5292/8371/Protocol_ on_Extradiction.pdf> accessed 5 January 2017).

88 Milliken T \& Shaw, J (with contributions from Emslie RH, Taylor RD \& Turton C) (2012) The South Africa-Viet Nam rhino horn trade nexus: A deadly combination of institutional lapses, corrupt wildlife industry professionals and Asian crime syndicates. Traffic Report. Johannesburg: TRAFFIC. 3, 14 . 
consumption of rhino horns and is slow in dealing with implicated individuals. ${ }^{89}$ Thirdly, Vietnam has failed to enforce cites implementing legislation, which would be instrumental in the fight against rhino poaching. ${ }^{90}$

The laws on rhino poaching have to be revisited, to inculcate activities of the second and third stages of the networks that operate outside South Africa. South Africa has no extradition agreements with Mozambique and Vietnam. ${ }^{91}$ A combination of the use of extraterritorial jurisdiction, extradition agreements or ad-hoc extradition arrangements, international cooperation among the SADC and CITES states parties will lead to increased prosecution of the kingpins and other members of the higher echelons.

The use of the current definition of the conviction rate should be revisited to have a more reflective assessment of the progress in the fight against rhino poaching. South Africa's police and the NPA should adopt other benchmarks of success other than the use of the conviction rate. The use of the trial-based perspective as noted by the South Africa Law Commission will measure the effectiveness of the criminal justice system as a whole rather than artificially isolate its constituent elements. For this reason, it is useful to measure the numbers of convictions compared with the number of cases reported to the police to get a sense of how effectively the police and prosecution authority work together to hold perpetrators of crime accountable for their actions. ${ }^{92}$

A combination of the use of extraterritorial jurisdiction, extradition agreements or ad-hoc extradition arrangements, international cooperation among the SADC and CITES states parties will produce a reflective conviction rate. First, the conviction rate will present the number of conviction against the number of arrests, withdrawal of charges, and prosecution of the same. Secondly, it will include the prosecution of the higher stages of transportation and distribution. Thirdly, the conviction rate will present the prosecution of members of networks as a pseudo- corporate crime rather than the current mode of prosecution, which relates to environmental crime as an individual crime.

89 Vietnam's Illegal Rhino Horn Trade: Undermining the Effectiveness of cITEs < vea.gov.vn/ en/news/news/Pages/Rhino-horn-claim-unfounded.aspx> accessed 30 December 2016.

Republic of Viet Nam, Government Decree No. 82/2006/ND-CP on Management of Export, Import, Re-export, Introduction from the Sea, Transit, Breeding, Rearing and Artificial Propagation of Endangered Species of Precious and Rare Wild Fauna and Flora (Aug. 10, 2006), <http://vbqppl.moj.gov.vn/vbpq/en/Lists/Vn\%2obn\%2ophp\%2olut/View_Detail .aspx?ItemID=5158> accessed 30 December 2016.

91 Extradition and Mutual Legal Assistance in criminal matters treaties <http://www .justice.gov.za/ilr/mla.html> accessed 5 January 2016.; Chu, Duc MANH v S Unreported South Gauteng High Court Criminal Case A407/11, judgment delivered 13 March 2012. 